University of Nebraska - Lincoln

DigitalCommons@University of Nebraska - Lincoln

Agronomy \& Horticulture -- Faculty Publications

Agronomy and Horticulture Department

$4-1975$

Inheritance of Seed and Seedling Color in Sweetclover

H. J. Gorz

James E. Specht

University of Nebraska-Lincoln, jspecht1@unl.edu

Francis A. Haskins

University of Nebraska-Lincoln, fhaskins@neb.rr.com

Follow this and additional works at: https://digitalcommons.unl.edu/agronomyfacpub

Part of the Plant Sciences Commons

Gorz, H. J.; Specht, James E.; and Haskins, Francis A., "Inheritance of Seed and Seedling Color in Sweetclover" (1975). Agronomy \& Horticulture -- Faculty Publications. 289.

https://digitalcommons.unl.edu/agronomyfacpub/289

This Article is brought to you for free and open access by the Agronomy and Horticulture Department at DigitalCommons@University of Nebraska - Lincoln. It has been accepted for inclusion in Agronomy \& Horticulture -Faculty Publications by an authorized administrator of DigitalCommons@University of Nebraska - Lincoln. 


\title{
Inheritance of Seed and Seedling Color in Sweetclover ${ }^{1}$
}

\author{
H. J. Gorz, J. E. Specht, and F. A. Haskins ${ }^{2}$
}

\section{ABSTRACT}

Eight seed colors, conditioned by two independent pairs of genes, were identified in sweetclover (Melilotus alba Desr.). The seed colors resulted from all combinations of two embryo and four seed coat phenotypes. Only four of the seed colors were recoverable in true-breeding form. Conventional genetic tests revealed that $Y / y$ alleles determined the absence or presence, respectively, of green pig. mentation in both the embryo and seed coat of fully mature seeds. Absence of green was dominant in both seed parts. The $C / c$ alleles conditioned the presence or absence, respectively, of brownish pigmentation in the seed coat and red pigmentation in seedlings with the presence of pigmentation being dominant.

Additional index words: Melilotus alba Desr., Embryo color, Seed coat color.
GEED color in sweetclover (Melilotus alba Desr.) is $\mathcal{S}$ determined by the combined effects of pigments in the seed coat and the embryo. The brownish-yellow seed color of most commercial varieties results from yellow embryos surrounded by grayish-brown seed coats. However, true-breeding strains with dark green seeds exist, which possibly trace to the single green-seeded plant discovered by Fowlds (1) in 1933.

\footnotetext{
${ }^{1}$ Contribution from the ARS, USDA, and the Nebr. Agr. Exp. Stn., Lincoln. Published as paper no. 3751, journal series, Nebr. Agr. Exp. Stn. under prcject 12-27. Received Aug. 12, 1974.

${ }^{2}$ Research Geneticist, ARS, USDA; graduate assistant in agron.; and Bert Rodgers Professor of Agronomy, U, of Nebr., Lincoln, $\mathrm{NE} 68503$, respectively.
} 
Dark green seeds consist of green embryos and brownish-green seed coats. Fowlds (I) also isolated a strain with pale yellow seeds composed of yellow embryos and white (colorless) seed coats.

In studying the inheritance of seed color, Fowlds (1) used natural hybrids between green-seeded and yellow-seeded plants, as well as between plants with pale yellow and yellow seeds. Although his data were quite limited in some instances, he concluded that green seed color was inherited as a monogenic recessive. Pale yellow seed color also was recessive to yellow. On the basis of limited data from a cross involving green seed coat $X$ white (colorless) seed coat, Fowlds (1) suggested that complementary factors were necessary for the expression of seed coat color.

Hartwig (2) also studied the inheritance of yellow and green embryo color, using a green-seeded strain supplied by Fowlds (1). He concluded that yellow was a simple dominant to green, but observed that the color of $F_{1}$ embryos usually resembled that of the maternal parent. A gene-cytoplasm interaction was proposed, but environment also seemed to be a major factor in determining $F_{1}$ embryo color.

Swenson (3) completed the inheritance study of green $X$ pale yellow seeds, which had been carried only to the $F_{1}$ generation by Fowlds (1). He concluded that various combinations of two independent gene pairs $(Y / y$ and $C / c)$ conditioned the four seed colors observed. $Y$ - and $y y$ genotypes produced yellow and green embryos, respectively, regardless of seed coat color. In the presence of $C$, yellow or green color also developed in the seed coat, but in its absence, the seed coat was colorless. A 9:3:4 ratio of the three seed coat phenotypes (yellow:green:colorless) in $\mathbf{F}_{2}$ appeared to confirm the postulated gene action.

The present work was initiated to provide suitable genetic stocks for a biochemical analysis of the pigments involved in the various seed colors. Because the stocks used in the cited investigations were not available, a study was conducted to determine whether the inheritance of the seed colors used in our work was similar to that reported earlier. During the study, a relationship between seed color and red pigmentation in seedlings (previously unreported in sweetclover) was discovered and investigated.

\section{MATERIALS AND METHODS}

Three experimental strains of $M$. alba were the source of the three true-breeding seed colors available at the beginning of this study. Seeds of the usual brownish-yellow color, called medium yellow (MY) in this study, and dark green (DG) seeds were obtained from two experimental strains of sweetclover (R1 and N1, respectively). A single light-yellow (LY) seed (designated JF-1), found in a commercial lot of common white sweetclover, bred true for that phenotype and probably was similar to the pale yellow mutant observed by previous workers. Five other seed colors were observed in progenies derived from crosses involving the three experimental strains. These were designated as medium green (MG), light green (LG), olive-green (OG), yellow-green (YG), and silver-green (SG). The SG phenotype bred true; thus, a fourth true-breeding strain was available for this study.

Only the progeny of DG $\times$ LY and SG $\times$ MY were analyzed in detail. Since subsequent evidence showed that the $\mathbf{F}_{1}$ genotypes from the two crosses were alike, data from the two crosses beyond the $F_{1}$ generation were combined. Appropriate $\chi^{2}$ tests were applied to the ratios obtained before and after pooling.

Plants from which seed was to be harvested, were grown singly in $10-\mathrm{cm}$ clay pots in a greenhouse; natural light was supplemented throughout the night with incandescent light. Plants to be used only for classification of seedling color were grown in 1-pint (.47 liter) plastic-coated milk cartons in growth chambers providing continuous light (cool white fluorescent lamps, approx. 10,000 lux) and constant temperature (approx. $23 \mathrm{C})$. A mixture of four parts soil, one part sand, and one part peat was used as a growth medium. All seeds were handscarified before being planted.

For crosses, flower buds of the female parent were emasculated and then immediately pollinated with pollen from the appropriate male parent. For self-pollination, individual racemes were rolled between the thumb and forefinger when the flowers were fully opened. In some cases, the developing pods were enclosed in clear plastic tape to prevent shattering of the mature seeds.

Seeds in each observed progeny were visually classified according to overall seed color. This information provided a simultaneous classification for both embryo and seed coat color, since each seed color resulted from a unique combination of the underlying embryo and seed coat colors (Table 1). However for confirmation, several seeds of each progeny phenotype were always separately classified for seed coat color and embryo color. This was accomplished by cutting a small section from the coteyledonary end of each seed and then examining the exposed embryo and portion of the seed coat under a dissecting microscope. In some instances, seed coats were completely removed from seeds that had been kept moist for several hours; phenotypes of embryos and seed coats were then determined.

The presence or absence of red pigmentation in seedlings was easily determined by visual examination after 2 to 3 weeks of growth. Because differences in pigmentation were especially pronounced when seedlings were grown in growth chambers, only chamber-grown plants were used for classification of seedling color.

\section{RESULTS AND DISCUSSION}

Two embryo and four seed coat phenotypes produced the eight different seed colors shown in Table 1. Symbols designating each seed color also are shown. The four seed colors recoverable as true-breeding lines were MY, LY, DG, and SG. The remaining four phenotypes were transient types that did not reappear in progeny grown from those seeds.

Embryos of mature seeds were found to be either yellow or green. In immature seeds, however, all embryos were green. The yellow phenotype resulted from the loss of green pigment in maturing embryos of the appropriate genotype. On the other hand, the yellow embryos regained their green color during the early stages of germination in the light, and soon were indistinguishable from green embryos.

Seed coats from MY seeds were brown; those from SG seeds were green; and those from LY seeds essentially colorless. Seed coats from DG seeds were much darker than those from the other true-breeding seed colors; paper chromatography revealed that they contained both brown and green pigments. As with embryos, green pigment was present initially in seed coats of all developing seeds, but was lost from the nongreen genotypes as they matured. Unlike embryos

Table 1. Eight seed color phenotypes arising from various combinations of two embryo and four seed coat phenotypes.

\begin{tabular}{|c|c|c|c|c|}
\hline \multirow{2}{*}{$\begin{array}{c}\text { Embryo } \\
\text { phenotypes }\end{array}$} & \multicolumn{4}{|c|}{ Seed coat phenotypes ${ }^{*}$} \\
\hline & NG-B & $\mathrm{NG}-\mathrm{NB}$ & G-B & G-NB \\
\hline $\begin{array}{l}\text { Yellow } \\
(Y)\end{array}$ & $\begin{array}{l}\text { Medium } \\
\text { yellow } \\
\text { (MY) }\end{array}$ & $\begin{array}{l}\text { Light } \\
\text { yellow } \\
\text { (LY) }\end{array}$ & $\begin{array}{l}\text { Olive } \\
\text { green } \\
\text { (OG) }\end{array}$ & $\begin{array}{l}\text { Yellow } \\
\text { green } \\
\text { (YG) }\end{array}$ \\
\hline $\begin{array}{l}\text { Green } \\
\text { (G) }\end{array}$ & $\begin{array}{l}\text { Medium } \\
\text { green } \\
\text { (MG) }\end{array}$ & $\begin{array}{l}\text { Light } \\
\text { green } \\
\text { (LG) }\end{array}$ & $\begin{array}{l}\text { Dark } \\
\text { green } \\
\text { (DG) }\end{array}$ & $\begin{array}{l}\text { Silver } \\
\text { green } \\
\text { (SG) }\end{array}$ \\
\hline
\end{tabular}

$\mathrm{G}=$ green plgmentation; $\mathrm{NG}=$ no green pigmentation; $\mathrm{B}=$ brown pigmentation; and NB = no brown pigmentation. 
however, nongreen seed coats did not regain their green color when the seeds were germinated in the light.

Since seed coats are maternal tissue, seed coat color is determined by the genotype of the plant upon which the seed develops, rather than by the genotype of the embryo within that seed. Consequently, all seeds on an individual plant have the same seed coat phenotype. The only segregation observable in the selfed seeds from a heterozygous plant is for embryo color. Segregation for seedling color is observable in young seedlings grown from such selfed seeds. However, segregation for seed coat color can be determined only by advancing the progenies an additional generation (i.e., classifying seed coat colors of seeds produced on plants grown from the selfed seeds).

Since true-breeding lines with green embryos always contained green pigmentation in the seed coat, while those with yellow embryos were always devoid of green pigmentation in the seed coat, it was postulated that the same gene (s) conditioned the presence or absence of green in both the embryo and seed coat.

Seedlings from MY or DG seeds had red stems, and the veins on the underside of the first few leaves also

Table 2. Chi-square tests for goodness-of-fit to a $3: 1$ ratio in $F_{2}$ segregations for pigmentation in embryos, seed coats, and seedlings.

\begin{tabular}{|c|c|c|c|c|}
\hline \multirow[b]{3}{*}{ Statlstic } & \multicolumn{4}{|c|}{ Phenotypic characters ${ }^{*}$} \\
\hline & \multirow{2}{*}{$\begin{array}{c}\text { Embyro } \\
\text { color }\end{array}$} & \multicolumn{2}{|c|}{ Seed coat pigmentation $\dagger$} & \multirow{2}{*}{$\begin{array}{l}\text { Seedling } \\
\text { color }\end{array}$} \\
\hline & & Green & Brown & \\
\hline No, of famllies & 12 & 2 & 2 & 12 \\
\hline Phenotypes & $\mathrm{Y}: \mathrm{G}$ & NG:G & $\mathrm{B}: \mathrm{NB}$ & $R: G$ \\
\hline $\begin{array}{l}\text { Class distribution } \\
\text { (pooled) }\end{array}$ & $3,541: 1,245$ & $131: 45$ & $126: 50$ & $675: 253$ \\
\hline Sum of family $x^{2}$ s & 12.74 & 1.98 & 1.81 & 13.03 \\
\hline$x^{2}$, pooled data & 2.62 & 0.03 & 1.09 & 2.53 \\
\hline $\mathbf{P}$ & 0.10 to 0.20 & 0.80 to 0.90 & 0.20 to 0.30 & 0.10 to 0.20 \\
\hline$x^{2}$, heterogeneity & 10.12 & 1.95 & 0.72 & 10.49 \\
\hline $\mathbf{P}$ & 0.50 to 0.70 & 0.10 to 0.20 & 0.30 to 0.50 & 0.30 to 0.50 \\
\hline
\end{tabular}

Table 3. Chi-square tests for goodness-of-fit to a 2:1 ratio of segregating to nonsegregating $F_{3}$ families from dominant $F_{2}$ phenotypes with regard to embryo and seedling color.

\begin{tabular}{ccccc} 
& \multicolumn{2}{c}{$\mathrm{F}_{3}$ familles observed } & & \\
\cline { 2 - 3 } $\begin{array}{c}\text { Phenotypic } \\
\text { character }\end{array}$ & Segregating & $\begin{array}{c}\text { Non- } \\
\text { segregating }\end{array}$ & $\chi^{2}$ & $\mathrm{P}$ \\
\hline Embryo color & 85 & 46 & 0.187 & 0.50 to 0.70 \\
Seedling color & 33 & 15 & 0.094 & 0.70 to 0.80 \\
\hline
\end{tabular}

Table 4. Chi-square tests for goodness-of-fit to a 3:1 ratio of dominant and recessive phenotypes in segregating $F_{8}$ progenies with regard to embryo color and seedling color.

\begin{tabular}{|c|c|c|c|}
\hline \multirow[b]{3}{*}{ Statistic } & \multicolumn{3}{|c|}{ Phenotyple characters ${ }^{*}$} \\
\hline & \multicolumn{2}{|c|}{ E mby ro color } & \multirow{2}{*}{$\begin{array}{c}\text { Seedling } \\
\text { color }\end{array}$} \\
\hline & Not taped & Taped $f$ & \\
\hline No. of families & 85 & 32 & 33 \\
\hline Phenotypes & $\mathrm{Y}: \mathrm{G}$ & $\mathrm{Y}: \mathrm{G}$ & $R: G$ \\
\hline $\begin{array}{l}\text { Class distribution } \\
\text { (pooled) }\end{array}$ & $26,931: 9,778$ & $1,334: 467$ & $1,143: 387$ \\
\hline Sum of family $x^{2} / s$ & 217.79 & 33.48 & 37.15 \\
\hline$\chi^{2}$, pooled data & 52.43 & 0.83 & 0.07 \\
\hline$P$ & $<0.005$ & 0.30 to 0.50 & 0.70 to 0.80 \\
\hline$x^{2}$, heterogeneity & 165.35 & 32.65 & 37.08 \\
\hline $\mathrm{P}$ & $<0.005$ & 0.30 to 0.50 & 0.20 to 0.30 \\
\hline
\end{tabular}
until fully mature. were red. The color was most intense in young seedlings and decreased markedly as the plants grew. Microscopic examination of cross-sections of red seedling stems revealed that the red color was present in a single layer of cells immediately below the epidermis. No red pigmentation was detected in seedlings grown from LY or SG seeds. Thus, seed and seedling color appeared to be directly related. However, no relationship was found between embryo color and seedling color since seeds with the same embryo color (e.g., MY or LY) differed in seedling color. In the true-breeding phenotypes, brownish color in the seed coat was always associated with red seedlings, while the absence of the brownish color was always associated with the absence of red pigmentation in seedlings. Furthermore in both true-breeding and segregating types, plants with red pigmentation always produced seeds with brown pigmentation in the seed coats, and plants lacking red pigmentation always produced coats lacking brown pigmentation. Therefore, it was postulated that the same gene (s) conditioned both brown pigmentation in seed coats and red pigmentation in seedlings.

Observed $F_{2}$ ratios did not differ significantly from the 3:1 expected in a single-gene mode of inheritance for each of the four phenotypic traits listed in Table 2. When yellow $(Y)$ vs. green $(G)$ embryo color and red $(R)$ vs. green $(G)$ stem color were studied in the same cross, an observed segregation of $497 \mathrm{YR}: 201$ YG:178 GR:52 GG was obtained in the $F_{2}$. This ratio was a good fit to a 9:3:3:1 $\left(\chi^{2}=6.10 ; \mathbf{P}=\right.$ 0.10 to 0.20$)$, indicating independent inheritance of two allelic pairs. Similarly, when no green (NG) vs. green (G) and brown (B) vs. no brown (NB) pigmentations in the seed coat were studied in the same cross, an observed segregation of 93 NG-B:38 NG-NB:33 G-B:12 G-NB was obtained in the $F_{2}$. This ratio also was a good fit to a 9:3:3:1 $\left(x^{2}=1.21 ; \mathrm{P}=0.70\right.$ to $0.80)$.

Among $\mathrm{F}_{3}$ families from $\mathrm{F}_{2}$ seeds with the dominant phenotype, satisfactory fits to the expected ratio of 2 segregating:1 nonsegregating were observed for both embryo color and seedling color (Table 3). Ratios of dominant to recessive phenotypes in segregating $\mathrm{F}_{3}$ families agreed well with a 3:1 for seedling color, but were significantly different from a 3:1 for embryo color (Table 4). Examination of the embryo color ratios from individual families revealed that of the 85 progenies observed, 19 were significantly different from a $3: 1$ at the $5 \%$ level, and all but one of these had an excess of green embryos. A similar excess of green seeds was observed by Swenson (3) in six of seven segregating progenies with significant $\chi^{2}$ values. In the present study, of the 66 families that fit a $3: 1$ ratio, 45 also had an excess of green embryos. Differential shattering of pods was hypothesized as the cause of the aberrant ratios. Sweetclover pods shatter readily unless they are harvested while still immature or are held in place with tape until mature. Developing pods on 32 segregating plants were held in place with cellulose tape and harvested when fully mature. Ratios based on seed harvested from these plants provided a satisfactory fit to a 3:1 for yellow and green embryos (Table 4). It appears therefore, that pods containing seeds with yellow embryos shattered more readily than those with green embryos. 
Table 5. $F_{2}$ and $F_{3}$ genotypes and phenotypes, with expected frequencies, derived from a self-pollinated $Y_{y} C c F_{1}$ plant, assuming two independent allelic pairs controlling seed and seedling color.

\begin{tabular}{|c|c|c|c|c|c|c|c|c|c|c|c|}
\hline & \multirow[b]{3}{*}{ Genotype } & \multicolumn{5}{|c|}{$\mathbf{F}_{2}{ }^{*}$} & \multicolumn{5}{|c|}{$\mathrm{F}_{3}{ }^{*}$} \\
\hline & & \multirow{2}{*}{$\begin{array}{l}\text { Expected } \\
\text { freq. }\end{array}$} & \multicolumn{4}{|c|}{ Phenotype } & \multirow{2}{*}{$\begin{array}{c}\text { Expected } \\
\text { freq. } \neq\end{array}$} & \multicolumn{4}{|c|}{ Progeny phenotypes from corresponding $\mathrm{F}_{2}$} \\
\hline & & & Seed & Embryo & Seed coat ${ }^{\dagger}$ & Seedling & & Seed & Embryo & Seed coat ${ }^{\dagger}$ & Seedling \\
\hline \multirow[t]{6}{*}{. } & $\begin{array}{l}\text { YYCC } \\
\text { YYCe }\end{array}$ & $\begin{array}{l}1 \\
2\end{array}$ & $\begin{array}{l}\text { MY } \\
\text { MY }\end{array}$ & $\begin{array}{l}\mathrm{Y} \\
\mathrm{Y}\end{array}$ & $\begin{array}{l}\text { NG-B } \\
\text { NG-B }\end{array}$ & $\begin{array}{l}\mathrm{R} \\
\mathrm{R}\end{array}$ & 3 & $\begin{array}{l}\text { All MY } \\
\text { All MY }\end{array}$ & $\begin{array}{l}\text { All Y } \\
\text { All Y }\end{array}$ & $\begin{array}{l}\mathrm{NG}-\mathrm{B} \\
\mathrm{NG}-\mathrm{B}\end{array}$ & $\begin{array}{l}\text { All } R \\
\text { 3R:1G }\end{array}$ \\
\hline & $\begin{array}{l}\text { YyCC } \\
\text { YyCe }\end{array}$ & $\begin{array}{l}2 \\
4\end{array}$ & $\begin{array}{l}\text { MY } \\
\text { MY }\end{array}$ & $\begin{array}{l}\mathrm{Y} \\
\mathrm{Y}\end{array}$ & $\begin{array}{l}\text { NG-B } \\
\text { NG-B }\end{array}$ & $\begin{array}{l}\mathrm{R} \\
\mathrm{R}\end{array}$ & 6 & $\begin{array}{l}\text { 3MY:1MG } \\
\text { 3MY:1MG }\end{array}$ & $\begin{array}{l}3 Y: 1 G \\
3 Y: 1 G\end{array}$ & $\begin{array}{l}N G-B \\
N G-B\end{array}$ & $\begin{array}{l}\text { All R } \\
\text { 3R:1G }\end{array}$ \\
\hline & YYec & 1 & MY & $\mathrm{Y}$ & NG-B & G & 1 & All LY & All Y & NG-NB & All G \\
\hline & Yyce & 2 & MY & $\mathrm{Y}$ & NG-B & G & 2 & $3 L Y: 1 L G$ & $3 \mathrm{Y}: 1 \mathrm{G}$ & NG-NB & All $\mathrm{G}$ \\
\hline & $\begin{array}{l}\text { yycc } \\
\text { yyce }\end{array}$ & $\begin{array}{l}1 \\
2\end{array}$ & $\begin{array}{l}\text { MG } \\
\text { MG }\end{array}$ & $\begin{array}{l}\mathbf{G} \\
\mathbf{G}\end{array}$ & $\begin{array}{l}\text { NG-B } \\
\text { NG-B }\end{array}$ & $\begin{array}{l}\mathrm{R} \\
\mathrm{R}\end{array}$ & 3 & $\begin{array}{l}\text { All DG } \\
\text { All DG }\end{array}$ & $\begin{array}{l}\text { All G } \\
\text { All G }\end{array}$ & $\begin{array}{l}\text { G-B } \\
\text { G-B }\end{array}$ & $\begin{array}{l}\text { Al1 R } \\
\text { 3R:1G }\end{array}$ \\
\hline & yyec & 1 & MG & G & NG-B & G & 1 & All SG & All $G$ & G-NB & All G \\
\hline
\end{tabular}

A similar problem with differential shattering was observed previously in an inheritance study of chlorophyll deficiency in Melilotus officinalis (L) Lam. (unpublished data).

In the four true-breeding seed colors, the yellow seeds (MY and LY) always have yellow embryos with nongreen seed coats, whereas the green seeds (DG and SG) always have green pigmentation in both embryos and seed coats. The four transient seed colors shown in Table 1 (OG, YG, MG, and LG) have just the opposite relationship between embryo color and green pigmentation in the seed coat from that in the truebreeding types. For example, the $O G$ and YG seeds have yellow embryos but contain green pigmentation in the seed coat. Both of these types are obtained only by use of pollen from a yellow-seeded plant in crosses with appropriate green-seeded plants. On the other hand, MG and LG seeds occur only as segregants with MY and LY, respectively, in the selfed progenies of plants heterozygous for embryo color. These seeds have green embryos but are devoid of green pigmentation in the seed coat, because the seed coat is determined by maternal plants carrying the genotype for lack of green.

Results of this study differ from those of Swenson (3) in the relationship between seed color and seedling color and in the postulated mode of inheritance of seed coat color. Swenson concluded that seed coat color resulted from interaction of the $Y / y$ and $C / C$ allelic pairs, in which a dominant $C$ allele was needed for the expression of color in the seed coat. This conclusion was based on the observation of only three seed coat phenotypes (yellow, green, and colorless) which occurred in the $F_{2}$ generation in a 9:3:4 ratio. However we have observed four seed coat phenotypes (NG-B, NG-NB, G-B, and G-NB) in the $\mathrm{F}_{2}$ in a 9:3:3:1 ratio. Swenson appeared to classify into a single colorless class the seed coat colors that we identified as green (G-NB) and colorless (NG-NB). Green seed coats lacking brown pigmentation (the G-NB class) appear somewhat translucent. Without close exami- nation, they could be misclassified as colorless (NG-NB).

Although the genetic stocks used and the conclusions concerning the inheritance of seed color differ in this study from those reported by Swenson (3), the genes involved are probably the same, and his gene symbols should be retained to avoid confusion in the literature. Our interpretation of the mode of inheritance of these alleles is as follows: a) The $Y / y$ alleles determine the absence or presence, respectively, of green pigmentation in both the embryo and the seed coat of fully mature seeds. The absence of green is dominant in both the embryo and seed coat. With respect to embryo color, the effects of the $Y / y$ alleles reported by Swenson (3) and the $I / i$ alleles proposed by Hartwig (2) appear very similar to the effects of the $Y / y$ alleles reported in this study. b) The $C / c$ alleles condition the presence or absence, respectively, of a brownish color in the seed coat and a red color in seedlings, with the presence of pigmentation being dominant. The postulated $F_{2}$ and $F_{3}$ genotypes and phenotypes arising from the action of these two independent pairs of alleles are shown in Table 5. In all progenies analyzed, the observed $F_{2}$ and $F_{3}$ phenotypes and segregation ratios agreed with expected ratios shown in Table 5.

Preliminary biochemical investigations indicate that the $C / c$ alleles are involved in a specific enzymatic step of flavonoid biosynthesis, and the $Y / y$ alleles appear to be involved in some aspect of chlorophyll metabolism in seeds during the final stages of maturation. Further biochemical studies are in progress.

\section{REFERENCES}

1. Fowlds, M. 1939. Seed color studies in biennial white sweetclover, Melilotus alba. J. Am. Soc. Agron. 31:678-686.

2. Hartwig, E. E. 1942. Inheritance of growth habit, cotyledon color and cup-leaf in Melilotus alba. J. Am. Soc. Agron. 34:160-166.

3. Swenson, S. P. 1942. Inheritance of seed color in biennial white sweetclover, Melilotus alba. J. Am. Soc. Agron. 34:452459 . 